\title{
Implementing task-based language education in primary education
}

\section{Lessons learnt from the Flemish experience}

\author{
Kris Van den Branden and Koen Van Gorp \\ KU Leuven Michigan State University
}

\begin{abstract}
This article provides a critical analysis of the language policy measures that were taken by the Flemish government (Belgium) to improve the quality of the teaching of the national language (Dutch) in compulsory education in Flanders and in the Flemish education system in Brussels. It builds on Van den Branden (2006a), which documented the implementation of task-based language teaching (TBLT) in primary, secondary and adult education in Flanders in the period between 1995 and 2005. Focusing on primary education, this article examines the different periods and trends in the government's attempts to push the innovation of Dutch language education, and analyses its impact on the practice of teaching the language of schooling. The article highlights the gradual shift in focus from introducing TBLT materials and supporting the individual teacher to mandating the design of a school-wide language policy involving the whole school team, and from a top-down implementation to a more bottom-up driven, collaborative innovation process. The major aim of the article is to identify the factors that impacted on the effects of the innovation policy, against the backdrop of the growing influx of pupils who do not acquire Dutch (the main medium of instruction) as their mother tongue.
\end{abstract}

Keywords: task-based language teaching, innovation, teacher education, language policy

\section{Introduction}

Flanders is the northern part of Belgium; it has its own regional government, which has been granted the power to determine its regional education policy. Dutch is the official language of the region and the medium of instruction in education. Brussels Capital Region is officially bilingual, but has separate educa- 
tion systems, one Dutch-medium and one French. Flanders shares its Dutch standard language with the Netherlands, and there are only minor differences (mainly related to pronunciation and lexis) between the so-called "Flemish" version of the Dutch standard language and the one spoken in the Netherlands.

In 2006, researchers of the University of Leuven (KU Leuven) published a volume on the region-wide innovation of first and second language teaching of Dutch in Flemish primary and secondary education (Van den Branden, 2006a). A large-scale project, financed by the Flemish government, had been set up in the 1990s to support teachers in making the transition from a structure-based to a more task-based approach of language teaching. An expert centre on Dutch first and second language education (i.e., the Centre for Language and Education) was founded at the University of Leuven; the Flemish government financed this centre to (a) carry out research into effective Dutch language education, (b) develop inspiring tools, methods, materials and prototypes for Dutch primary and secondary schools, and (c) provide in-service training to practitioners in the field and inspire pre-service teaching education. The main reason why the government instigated and supported this innovation project was to bridge the social achievement gap in language education, and education in general, between students of low socio-economic background (SES) and ethnic minority students on the one hand, and students with a higher SES-background who acquired Dutch as their mother tongue on the other hand. Furthermore, through raising the quality of Dutch language education, all students were expected to become more proficient users of Dutch, raising their chances to do well in education and outside school. In this regard, it should be emphasized that the Flemish government did not favour bilingual teaching for non-native speakers of Dutch: no initiatives were taken to foster ethnic minority students' acquisition of their mother tongue, nor to valorise their mother tongue proficiency in the mainstream education system. The focus of the government was entirely on the education of the official language of the region.

Researchers, syllabus developers, teacher educators and school counsellors participated in this top-down initiated attempt to raise the quality of Dutch language teaching. Van den Branden (2006a), which is generally seen as one of the first scientific reports on the implementation of task-based language teaching (TBLT) on a large scale, reports on the momentum that was created between 1995 and 2005, and the gradual progress that was made in sensitizing (language) teachers and principals, supporting their professional development, and raising the overall quality of Dutch language teaching.

Fifteen years after the publication of that volume, language teaching in Flanders has been reported in national newspapers to be in a state of crisis. Over the last fifteen years, international comparisons of students' achievements based on 
standardized tests for reading comprehension (PISA for 15-year old students and PIRLS for Grade 4 pupils in primary school) have shown a gradual drop in performance levels in Flanders. The comparison between PIRLS 2006 and PIRLS 2016 shows that the average reading comprehension skills of 10-year old pupils in Flemish schools dropped significantly (Tielemans, Vanlaar, Van Damme, \& De Fraine, 2019). Moreover, there is still a large achievement gap between lowSES and high-SES pupils, and between native speakers of Dutch and non-native speakers.

Against the backdrop of these worrying trends, this paper aims to update the story of the government's attempt to enhance the quality of Dutch language education. This will include an update of the government's and practitioners' perceptions, support, and implementation of task-based language teaching since 2006. The main focus of this article will be on primary education. First, we will discuss some of the main characteristics of the Flemish education system, particularly those that can help or hinder the implementation of innovations. Secondly, we will document the different periods and trends in the innovation of Dutch language teaching, and the implementation of TBLT, in Flemish schools and Dutch-medium schools in Brussels. In particular, we will document how the Leuven Centre for Language and Education, the government and school counsellors gradually shifted their locus of concern from the individual teacher to the whole school team, and from a top-down implementation to a more bottom-up driven, collaborative innovation process. We will try to identify the factors that impacted on the effects of the innovation process and on the quality of Dutch language teaching in Flanders and Brussels. This, then, will constitute the basis for a number of conclusions and recommendations that might be relevant for the innovation of language teaching in countries and regions outside Belgium.

\section{The Flemish education system}

In this paragraph we will discuss a number of features of the Flemish education system that are relevant to the purposes of this article. They relate to the pupil population, school autonomy, and curricular demands, respectively.

\section{Pupil population}

In Flemish primary and secondary education, L1 Dutch speakers and L2 Dutch learners (i.e., students who mainly speak a language other than the language of instruction at home) are in the same classrooms, are taught the same curriculum and are expected to achieve the same objectives of the official curriculum. 
For over 30 years, the heterogeneity in language background of the Flemish student population has increased continuously, and the proportion of students with another mother tongue than Dutch has steadily increased. As in many other countries, the proportion of L2 speakers varies according to region (e.g., Flemish versus Brussels-Capital Region) and areas (rural versus urban). In 2018, on average $18.5 \%$ of the students in primary education in Flanders were L2 learners; in the Brussels-Capital Region the average was $72.7 \%$ (Lokale Inburgerings- en Integratiemonitor, 2019). In Flanders, Dutch second language learners are predominantly found in the major cities. For example, in 2018, the average percentage of L2 learners in Antwerp (the largest city in Flanders) was 44.8\%, and $33 \%$ in Ghent (the second largest city in Flanders) (Lokale Inburgerings- en Integratiemonitor, 2019). In those cities most L2 learners are enrolled in a small number of schools with large populations of Dutch L2 learners, from $50 \%$ to more than $90 \%$. Only students who enter the country and the education system at a later age ("newcomers") receive $\mathrm{L}_{2}$ instruction outside of the regular classroom for a couple of hours per week during their first year in primary education. In secondary education they are pulled out for one school year in separate "reception classes". In these classes, newcomers receive intensive L2 instruction focusing on acquiring Dutch and other key skills which prepares them for their integration into the regular classroom.

\section{School autonomy}

Official schools subsidized by the Flemish government are granted a high degree of autonomy. The Flemish government issues official attainment targets, but grants schools the autonomy to decide freely on their teaching methods, curricula, timetables and staff appointment. There is no system of standardized or centralised testing, neither in primary, nor in secondary education. School teams have an obligation to evaluate and follow up their students' progress and performance with regard to the official objectives, but determine autonomously which methods, tests or instruments they will use. Once every six years, schools are visited by the Flemish Inspectorate. They examine the extent to which school teams develop their professional competence, raise and monitor the quality of their education, and work on all the official objectives. Repeated negative audits may impact school budget and official recognition by the government. All schools are supported by the educational networks they are associated with: these networks have a substantial impact on school organisation, in view of the fact that they offer schools a lot of support with regard to curriculum design (based on the official objectives), staff members' continuous professional development, assessment of student achievement, and the choice of pedagogical approaches and syllabi. Com- 
mercial publishers are therefore keen to adapt their methods and coursebooks to the guidelines and curricula issued by those networks.

\section{Curricular demands}

With respect to language education, the official attainment targets for the acquisition of Dutch (as the main medium of instruction) issued by the government focus on communicative language proficiency in terms of "Can Do statements", for example, "Students can write a letter to a familiar person to deliver a personal message or experience" (attainment target 4.3 for Dutch in primary education). In addition to Can Do statements, the attainment targets explicitly describe the explicit knowledge of vocabulary, grammar, spelling, strategies and other discrete units, and the attitudes that students should have developed at the end of an educational cycle, that is, for primary education the last year of kindergarten $\left(\mathrm{K}_{3}\right.$; 5-year olds) and Grade 6 (12 year-olds), and for secondary education Grades 8 (14 year-olds), 10 (16-year olds), and 12 (18-year olds). The official attainment targets are considered to be minimum goals that at least two thirds of the student population should reach.

Since 2002, the Flemish Department of Education has ordered regular national assessments (about every five to six years) to monitor the extent to which schools attain these targets with their students. These, however, are administered in a representative sample of schools only, not in all schools. Consistently, those national assessments report a clear achievement gap. A substantial proportion of L1 and L2 Dutch speakers, especially children from parents with a lower socioeconomic background, underachieve in Flanders. This achievement gap is corroborated in large-scale international standardized language tests like PIRLS for primary education and PISA for secondary education. Analysing the PISA data from 2003 till 2015, Franck and Nicaise (2019) claim that individual student characteristics, in particular students' socio-economic status (low-SES) and home language (other than Dutch), contribute the most to this achievement gap both for Dutch language skills and mathematics, as well as to students' school well-being. Low-SES and L2 students seem to be particularly vulnerable in the Flemish education system. For example, in the latest national assessment of reading comprehension skills at the end of primary education, only $71 \%$ of the student who do not speak Dutch at home reached the attainment targets compared to $88 \%$ of the students who speak only Dutch at home. In a similar vein, $74 \%$ of students with a low SES reached the attainment targets compared to $91 \%$ of the students with a high SES (Steunpunt toetsontwikkeling en peilingen, 2019). Additionally, the overall average performance of Flemish students and the proportion of students with excellent scores have dropped consistently in both national and interna- 
tional assessments. That has raised major concerns about the quality of education in Flanders in the media, which some have referred to as the "PIRLS shock", and has created a sense of urgency among policy makers and other educational stakeholders.

In the next section, we will describe, and critically evaluate, the different attempts made by the government, researchers and educational networks since the 1990 s to address the above-mentioned challenges and make a contribution to raising the quality of Dutch language education.

\section{Top-down implementation of TBLT in Flanders: The early years}

In 1990, as a response to the first reports on the achievement gap between L2 Dutch speakers and L1 Dutch speakers in education, the Flemish government set up a nationwide Educational Priority Policy (EPP) targeting social inequity in Flemish education and society. As part of that policy, the Centre for Language and Education (CLE) was founded at the University of Leuven to support schools in raising the quality of their Dutch language education. In a first stage, the CLE developed prototypical teaching materials for teachers in primary and secondary schools, for both the regular classroom and for reception classes, and organized professional development courses to help teachers provide effective L2 vocabulary instruction. However, the emphasis on L2 vocabulary acquisition seemed to intensify teachers' inclination to focus on the teaching of discrete units, rather than supporting their students into developing functional language skills. Therefore, inspired by the international research-based literature, the CLE turned to task-based language teaching (TBLT).

\section{Implementing TBLT}

In their workshops and publications, the CLE made clear to teachers that a focus on form should preferably be integrated in meaningful activities, by making use of relevant, motivating and challenging tasks. The CLE adopted Van den Branden's definition of a task: "an activity in which a person engages in order to obtain an objective, and which necessitates the use of language" (Van den Branden, 2006b, p.4). For instance, primary school pupils who read an informative text to try and find out how dinosaurs got extinct are performing a goal-oriented language task (in this case, a reading comprehension task aimed to gather new knowledge). If these pupils are asked, in addition, to report what they have found out to other students who have read another text on the same topic, then the language task becomes a complex task involving both reading comprehension, listening, and 
speaking. Using texts of different complexity levels and having students collaborate in heterogeneous groups with respect to language proficiency, are two ways that enable teachers to differentiate and address the needs of both L1 and L2 learners in this integrated task. Meaning is primary in tasks, although the discussion of the texts and tasks may give rise to an explicit focus on form, for instance the explicit discussion of the meaning of difficult words or the explicit rule explanation of a grammar rule that features prominently in the given texts.

A nationwide, government-subsidized support program for the implementation of TBLT was rolled out:

From the early 1990s, a cycle of action and reflection was set up, accompanying the introduction of task-based syllabuses and the training of teachers at various levels of education. Working together with several hundred school teams, educational counsellors, policy makers and educationalists, the Centre for Language and Education supported the implementation of task-based language teaching in Flemish education, step by step, carefully monitoring the reactions of all the parties involved and redressing the implementation strategies when necessary.

(Van den Branden, 2006b, p 14)

The CLE adopted three strategies to support the implementation of TBLT in Flanders: (1) the development of task-based curricula and syllabi, (2) professional development courses for teachers and school teams, and (3) research to examine the impact of TBLT on classroom practices and students' language proficiency development.

The impact of materials and workshops

Clear progress was gradually made. In the initial stage, primary and secondary teachers in Flanders had little experience with second language instruction; their approach to language teaching was largely structure-based and form-focused. To provide teachers with good examples of task-based language instruction the CLE decided to develop prototypical materials in so-called "source books": these were not full-blown syllabuses but rather packages that contained a number of workedout examples of task-based lesson activities that illustrated the importance of rich and comprehensible input, cooperative learning activities aiming to stimulate learner participation and interaction, pushed output, and the integration of meaningful skill-based work and focus on form. Different source books catered to the needs of teachers in primary and secondary schools and in mainstream versus reception classes. A few years later, the CLE also produced task-based syllabi which were intended to guide teachers through a fully fleshed-out task-based language curriculum in mainstream classes with both L1 and L2 learners, and deal 
with the difficult choices involved in sequencing and structuring tasks in terms of difficulty and complexity (Van den Branden, 2006a). These ready-made materials were developed by teams of professional task-based syllabus designers at the CLE and were introduced to teachers at professional development courses and workshops for individual teachers. The courses and workshops mainly addressed schools with a relatively large proportion of L2 speakers of Dutch and children with a low socio-economic background. In most of those schools, the principals and boards of those schools, in collaboration with external school counsellors, had taken the decision to adopt the textbooks, while the teachers who had to work with them in the classroom were not always involved in the decision-making process. Teachers' questions and concerns were supposed to be addressed in professional development courses offered either by the CLE, school counsellors or the publishers.

In most cases, teachers participated in these in-service teacher courses on a voluntary basis, and as individuals. Many school teams sent one teacher to the courses, who was expected to pass on key insights to their colleagues who did not attend the meeting. In the courses, teachers were informed on how to use the task-based materials in the classroom, rather than being invited to engage in collaborative dialogue or design teams; neither were teachers provided with on-thejob support in the classroom, mainly because the funding was lacking to organise intensive trajectories. Parallel to these in-service teacher training courses, the CLE attempted to stimulate teacher educators in pre-service training to integrate TBLT in the regular curriculum. However, this attempt turned out to be only partially successful. At that time, teacher educators were not entirely convinced that TBLT was the most effective approach to language teaching because empirical evidence appeared to be lacking, and were willing to devote only limited attention to the needs of L2 learners in separate modules or weeks (e.g., "the week of the migrant”).

Qualitative research showed that pupils were very enthusiastic about the new, task-based syllabuses. In turn, their enthusiasm helped to overcome some of the teachers' inhibitions and doubts. However, many teachers were found to adapt the motivating and challenging tasks in the syllabus to fit their more traditional teaching methods (François, 2005; Colpin \& Van Gorp, 2007; Van den Branden, 2006c). In a 2005 study into the perceptions and actions of 73 primary school teachers who used De Toren van Babbel (a task-based coursebook for primary education), fifty percent of the teachers indicated that they regularly adapted tasks; the other fifty percent indicated that they sometimes did (François, 2005). The adaptations most typically had to with changing the pre-task phase to teach vocabulary explicitly, simplifying the tasks, replacing the interactive formats with whole-classroom teaching, and making changes to save time. Overall, 
many teachers were inclined to introduce a structure-based focus before, during or after the meaningful tasks. The teachers in François' 2005 study justified these modifications as a response to their students' poor language proficiency (i.e., the students need more linguistic stepping stones to be able to perform the challenging tasks). In addition, the teachers complained about the vagueness of some of the task goals, and the lack of guidance in the syllabus with regard to providing interactional support and feedback to the students while they were performing the tasks. Apparently, adopting task as a unit of analysis for syllabus design and classroom activity proved quite a challenge for many teachers. As reported in Van den Branden (2006c), offering on-the-job coaching did make a difference and enhanced teachers' implementation of the task-based syllabi, but this could only be offered to a limited number of teachers due to time and budget constraints.

\section{A revised syllabus}

Teachers' concerns were taken seriously by the task developers, who produced an improved version of the syllabus for primary education, called TotemTaal (Berben, Callebaut, Colpin, Geerts, Goethals, Vander Meeren, Vandommele, Van Gorp, \& Vanoosthuyze, 2007; Van Gorp, in press). In comparison with its predecessor, the new syllabus made improvements in terms of:

1. defining clear and specific task goals;

2. providing teachers with a rich collection of input-based, output-based, and integrated tasks which gradually increase in complexity;

3. integrating explicit guidelines on how to support learners and differentiate between them while they are performing tasks;

4. including assessment tasks that allow teachers and students to monitor progress.

The development of this new TBLT syllabus was funded by a commercial educational publisher and an educational network of school counsellors in Brussels (Devlieger \& Goossens, 2007), which supported the Dutch-medium schools in Brussels. During the first three years that Brussels schools implemented the syllabus, the Brussels educational network organized free in-service training and workshops for all schools, which focused on different aspects of TBLT. The school counsellors had meetings with headmasters, school teams, and individual teachers about the aspects of language teaching topics that they were struggling with. They gave workshops to school teams and provided personalized coaching opportunities to individual teachers. They engaged in feedback sessions with individual teachers about their use of the syllabus. They observed teacher classroom 
behaviour if the teacher allowed it, and reflected on their observations with the teacher.

In an explorative study, Van Gorp (2018) examined how the task-based assessment framework in the TBLT syllabus was received by the teachers and school counsellors in Brussels. The school advisors were found to be much more convinced of the value and potential of the assessment framework than the teachers, who sometimes found it too elaborate and too complicated. This finding further illustrates that although TBLT may seem like the most plausible answer to improve language instruction for academics, educationalists and school counsellors, it may not be the alpha and omega for teachers. The inconvenient truth is that many teachers struggle with TBLT at different levels. So, although the basic TBLT principles might be conceptually simple for teachers to grasp (Ellis, 2009; Long, 2015; Skehan, 1998), it can be hard for them to put these principles into practice when developing their own lesson materials (e.g., Erlam, 2016), or when organizing their own classroom activity (cf., Vandommele, Van den Branden, \& Van Gorp, 2018; Kubanyiova, 2012).

For one, the rationale behind TBLT is likely to clash with many teachers' deeply ingrained beliefs that students first need to know words and grammar rules before they can start combining and using them. In addition, TBLT is not just an innovation, but actually incorporates a range of innovations, all of which impact on teachers' regular classroom practice: TBLT not only means working with tasks, it also implies the frequent use of group and pair work, the frequent use of authentic or semi-authentic sources of input, and the use of tasks to assess students' progress and performance, amongst others. Moreover, tasks on paper (or "task-asworkplan", Breen, 1989) may differ considerably from tasks-in-action or tasks in authentic classrooms (e.g., Berben, Van den Branden, \& Van Gorp, 2007), in that students are likely to react in strange, unexpected or elaborate ways, when they are given more extended opportunities to interact. As a result, TBLT is bound to lead to a reduction of teacher control.

This is probably the reason why the great majority of teachers who participated in the available Flemish studies preferred to approach the implementation of TBLT in a gradual, piecemeal fashion. In Brussels, the implementation program was evaluated. After three years, qualitative research based on classroom observations spread in time (Devlieger, Goossens, Labath, \& Denolf, 2003) showed that the intensive support was found to have led to a significant improvement in the quality of the input the teachers offered, the variety of questions they asked, and the proportion of classroom activities with a functional, taskbased goal. However, strong differences were found between the teachers, who had been granted the autonomy to determine themselves how intensively they would be coached. Quantitative studies (Devlieger \& Goossens, 2003; Devlieger 
\& Goossens, 2004) indicated that teachers' regular use of the above-mentioned task-based syllabi had strong, significantly positive effects on their students' Dutch language development at the end of the first year of adoption. The studies also provided indications that the positive effects were stronger in schools that had been intensively supported by coaches than in schools that had received far less support. Overall, the project had taken a very successful start.

However, in later years, the acceleration in pupils' language development decreased, and some Brussels schools even lost some of the progress they had initially made (Devlieger \& Goossens, 2006). This seemed to indicate that some of the early positive impact had mainly resulted from a sense of urgency created by the heavy funding, the availability of materials and the increased presence of school counsellors on the floor. Teachers were likely to have been sensitized with regard to the primacy of language teaching and consequently devoted more attention, more intense energy and more classroom time to teaching language; the materials helped them to turn that enthusiasm into action. However, the spike did not continue over the next few years, which is in line with general insights in the diffusion and implementation of other innovations (Van den Branden, 2009). As the "novelty" of an innovation wears off, the old routine creeps in again, and after a while other - equally urgent or more urgent - innovations take over, as a result of which the original enthusiasm wanes and the innovative TBLT approach may get diluted to fit teachers' more routinized, standard classroom practices again. Moreover, the fact that many teachers regarded the implementation of TBLT in Brussels and Flanders as an external, top-down, mandated innovation may have deterred them from fully embracing the innovation.

\section{The challenge of implementing TBLT}

In the literature, TBLT is often described as an innovation suited to Western educational philosophy. Long (2015), for example, makes clear that TBLT's philosophical roots lie in a rich progressive educational tradition that is linked primarily to "Western" thinkers, like John Dewey (USA), Ivan Illich (Austria), and Paulo Freire (Brazil), who focus on "educating the whole person, learning by doing, rationalism, free association, learner-centeredness, egalitarian teacherstudent relationships, and participatory democracy" (Long, 2015, p.9). In addition, within the sociocultural tradition of Second Language Acquisition (SLA) research, task-based perspectives draw on the work of Vygotsky (for a recent overview, see Ellis, Skehan, Li, Shintani, \& Lambert, 2020). Some scholars have questioned the compatibility, usefulness and effectiveness of a task-based language learning approach in non-Western contexts, for example, in countries with a Confucian learning and teaching tradition (Littlewood, 2014). Other critiques 
relate to the difficulty of using TBLT in large classrooms, mixed-ability classes, foreign language contexts with limited opportunities to use the language outside the classroom and/or high-stakes, form-focused examinations, with beginning language learners and, in particular, young learners. Many of these critiques have been documented more extensively in Asian countries (however, note Prabhu's seminal work on task-based language teaching in India - Prabhu, 1987) than Western countries, however, the Flemish experience indicates that they also pertain to West-European contexts, and so may not be typically Asian. Whereas the early efforts to implement TBLT in Flemish classrooms can be considered a success, especially during the first couple of years (Van den Branden, 2006a), in the longer term the efforts seem not to have led to sustainable paradigmatic changes in the majority of Flemish language teachers' beliefs and classroom practices. This suggests that teachers' resistance against a task-based approach, and their reluctance to give up teaching language as a system of vocabulary and grammatical rules, might be more deeply rooted and universal than often assumed in the TBLT literature.

One of the main reasons why that would have been the case in Flanders is that some of the key conditions for educational innovations to be successful on a system-wide scale were not met. The research-based literature on successful educational innovations and school improvement (Barber, Kihn, \& Mofflit, 2011; Hargreaves \& Fullan, 2012; Mourshed, Chijoke, \& Barber, 2010; Schleicher, 2018) suggests the following features are of key importance:

- Key stakeholders in the educational innovation, particularly those who have to put it into practice, build up a sense of ownership and identify shared goals;

- At school level, the innovation is approached as a team-based endeavour, and provides individual teachers with the chance to cooperate, deliberate, team teach and learn from each other;

- Individual teachers, and school teams, receive on-the-job coaching and are supported (both logistically and pedagogically);

- At the local level, the innovation is planned, monitored and evaluated in a systematic way.

The available research in Flanders and Brussels all suggest that the top-down initiated reform in Flanders and Brussels focused too much, and too long, on individual teachers. Even if there was training and coaching on the classroom floor (for instance, in the Brussels innovation project), and some of it did lead to clear changes in the participating teachers' classroom behaviour, it was predominantly geared at individual teachers, in the first place those who were highly motivated to make their teaching more task-based. In most schools, that strategy led to growing disparities between different teachers' classroom practices within the same 
school, rather than leading to an overall improvement of the quality of language teaching pupils were offered throughout their school career.

Moreover, there was an issue of scale and funding. The governmentsubsidized project reported so far did not allow the CLE, the education networks and school counsellors to support all primary schools in Flanders. As mentioned above, priority was clearly given to schools with a large proportion of low-SES, non-native speaker pupils, as a result of which the great majority of Flemish schools was hardly engaged in the CLE-supported efforts to implement TBLT. At its peak, Totemtaal (the task-based syllabus) was used by just about $15 \%$ of Flemish primary schools. The other $85 \%$ worked with other commercial syllabi, which were much more eclectic, and which combined task-based activities with task-supported and Presentation-Practice-Production (PPP) activities. So, on a nation-wide scale, the innovation of language education was even slower, and more fragmentary, than in the schools targeted by the Educational Priority Policy. All of this underpinned the Flemish government's decision to adapt its language education policy in the sense that, at least on paper, more emphasis was put on teacher collaboration and joint, school-wide language policy making on a nationwide scale.

\section{School-wide language policy as a key driver}

In 2007, the Flemish government issued a decree which made it mandatory for each single officially subsidized primary and secondary school to design and implement a school-wide language policy. This regulation came in response to the research that showed that the Educational Priority Policy, although influential, did not have the desired, region-wide effects on (a) raising the overall quality of language education and students' performance in the language of schooling, and (b) bridging the achievement gap between low-SES pupils/L2 speakers of Dutch and high-SES pupils/L1 speakers of Dutch.

School-wide language policy was defined by the government as the joint, structural and systematic attempt of a school team to tailor its language education, and the way the teachers dealt with language across the curriculum, to the language learning needs of their students, and by doing so, to raise their overall achievement and development. Staff members of the same school team were strongly recommended to design a school-wide language policy plan together and to raise their students' Dutch language proficiency by taking concerted action across the curriculum. In line with the great importance the Flemish government attaches to school autonomy, schools were given a large degree of autonomy as to what their language policy would look like, what it would focus on, and how it 
would be implemented. Again, the Inspectorate was assigned the task to check the progress schools were making in implementing a school-wide language policy. It should be noted that around the same time, as part of austerity measures taken by the Flemish government, the funding for the above-mentioned CLE-project that supported Flemish and Brussels schools to bridge the social achievement gap and to raise the quality of their language education, was abruptly and severely cut. The CLE did publish two handbooks on the implementation of school-wide language policy, which were eagerly adopted by the educational networks and school counsellors in their support to schools, but those support actions were relatively limited (with school counsellors paying only two to four visits a year to most schools). As a result, Flemish schools were largely left to their own devices when it came to designing and implementing their school-wide language policy.

\section{The implementation of school-based language policy}

Between 2009 and 2014, the Flemish Inspectorate carried out a study into the early implementation of the new decree. Analysing schools' attempts to design and implement a school-wide language policy, the Inspectorate came to the following conclusions:

1. The number of schools that actually designed a school-wide language policy and wrote a policy plan, gradually increased over the years, and comprised more than $2 / 3$ of all schools in 2014 .

2. Whereas the Inspectorate saw schools improve in terms of describing SMART (specific, measurable, achievable, realistic and timely) goals, too few schools evaluated the impact of their actions on students' language development and overall academic achievement, and used that evaluation to redirect or revise their language policy.

3. Between 2009 and 2014 , most school teams were found to increase their use of interactive and communicative tasks in their language courses; however, these initiatives were mainly found in schools with relatively large proportions of L2 speakers of Dutch, and were largely confined to teaching Dutch as a subject. A large proportion of schools did not succeed in fostering students' Dutch language development across the curriculum. Particularly in secondary education, teachers of other subjects than languages showed low engagement to foster their students' language skills. In the majority of schools, actions mainly focused on extra-curricular initiatives (e.g., remedial teaching offered to low achievers outside regular classroom hours) or organisational, rather than pedagogical, measures (e.g., implementing rules regarding the use 
of heritage languages in the playground or installing a book corner or school library where students can read for leisure).

4. In a substantial proportion of schools, the language policy plan was designed and written by school principals and the language policy coordinator, and teachers were not fully involved in the design process. In many of those schools, many teachers showed little engagement to put the plan into practice. Overall, in the majority of schools, the impact of the governmental measure on the quality of language teaching in the classroom remained relatively limited.

5. The Inspectorate could report no data on the impact of the governmental policy on students' actual language development in view of the lack of national assessments and standardized exams.

On the basis of their research results, the Inspectorate formulated a number of recommendations for teachers and schools. Teachers were urged to specify their professional development needs in the area of Dutch language teaching and language policy; school teams were encouraged to use more interactive tasks, work more closely together, and monitor students' academic results more closely. Schools were urged to formulate explicit goals with respect to fostering Dutch language development across the curriculum, stimulate language diversity initiatives, and evaluate the impact of their language policy actions.

\section{Further empirical evidence}

The conclusions of the study by the Inspectorate are supported by Vanbuel's recent mixed-method study into the implementation of school-wide language policies in Flanders (Vanbuel, 2020). Vanbuel investigated the impact of the implementation of language policy in Flemish primary schools on students' reading comprehension skills and also carried out an in-depth, qualitative exploration of the language policy practice in six primary schools. In a sample of 28 primary schools (with more than 3000 students participating), she found no effect of the implementation of school-based language policy on pupils' Dutch reading comprehension skills. However, she did find a positive effect on technical decoding skills for reading.

Vanbuel speculates that this might be attributed to the fact that the teaching of those technical decoding skills comes in the shape of highly structured, explicit and direct instruction of sound-letter links and decoding written words and sentences. Reading comprehension, in contrast, is a much more complex process which involves all sorts of interactions between the reader and the text, between visual and non-visual information, and between the student's prior knowledge 
and the text. This requires a pedagogical approach that strikes a balance between the performance of meaningful reading comprehension tasks and an explicit focus on vocabulary, self-regulation, reading comprehension strategies, and text structures, amongst others (Castles, Rastle, \& Nation, 2018). In other words, for school teams it may be more feasible to design and implement a clear and coherent set of shared practices targeting decoding skills than the more complex and elusive reading comprehension skills. Teaching functional reading comprehension skills, whether in a task-based way or not, involves, amongst others, selecting relevant, motivating, challenging and carefully sequenced texts and tasks, interacting with the students about the contents and linguistic aspects of the text, integrating a focus on form and explicit strategy training where appropriate, assessing different dimensions of the students' comprehension of texts, and following up on that assessment with powerful feedback. Learning by doing, as a key principle of task-based language teaching, sounds simple, but what students are supposed to be doing when they read a text for comprehension, listen to authentic input, perform a goal-oriented writing task or learn to speak by speaking, is so complex that it can become downright intimidating for the average teacher.

A second possible reason why the implementation of a school-wide language policy was found not to impact on pupils' reading comprehension skills in Vanbuel's study may be related to the fact that among Flemish schools, there has been a reduced sense of urgency with regard to language teaching over the past ten years. There are indications that after the intensive language-aware period between 1995 and 2008 described above, a sense of "language fatigue" crept into the Flemish education system. This was also reflected in a decrease in the number of professional development courses with a focus on language development across the curriculum being offered to teachers. Meanwhile, other innovations gained momentum and became more prominent, some of the most outstanding examples being STEM education (i.e., the education of sciences, maths and technology) and the integration of modern technology in education. An in-depth analysis of the reasons why Flemish pupils lost ground in the PIRLS-survey (Tielemans, Vanlaar, Van Damme, \& De Fraine, 2019) revealed that while in PIRLS 2006 Flemish primary school teachers reported devoting an average of 146 hours per year to fostering reading comprehension skills, this number dropped to 84 in PIRLS 2016. Even if such numbers should be treated with caution because they are based on teachers' self-report data, they do illustrate that Flemish teachers' minds seem to have been preoccupied with other priorities than reading skills. The most recent annual report of the Inspectorate corroborates that for many primary schools in Flanders, reading comprehension, and language education in general, is not a top priority; the Inspectorate hopes that the PIRLS-shock will function as a wake-up call, and also is in favour of introducing standardised tests 
for reading comprehension in the future, because those would allow schools to follow up their students' progress more systematically.

\section{Four types of school-based language policy}

Vanbuel's in-depth exploration of the implementation of a school-wide language policy in six primary schools further illustrates the complexity of the challenge school teams face. Based on interviews, focus group meetings and classroom observations, she characterized the language policy of each of the six schools as belonging to one of four types. Following Kyriakides, Creemers, Antoniou, Demetriou, \& Charalambous (2015), those four types were based on a framework for effective school policies which hinges on two key dimensions: (a) the extent to which school teams base the improvement of their classroom practice on research evidence, and (b) the extent to which the school offers staff members a fruitful environment for joint continuing professional development (CPD), i.e., CPD aimed at putting the research-based principles of high-quality teaching to practice in the classroom and enhancing teacher collaboration while doing so.

In Vanbuel's study, only one out of the six schools qualifies as a school with a structural, school-wide and strategic school language policy that scores high for both dimensions. As for the first dimension, many Flemish school teams primarily associate language policy with extra-curricular remedial teaching that is offered to pupils who underachieve in language courses, as a result of which many teachers do not feel pushed to explore the research evidence and modify their regular classroom practice across the curriculum accordingly. As for the second dimension, both Vanbuel's study and the international TALIS survey (Van Droogenbroeck, Lemblé, Bongaerts, Spruyt, Siongers, \& Kavadias, 2019) show that Flemish teachers score relatively low when it comes to collaborating with colleagues, team teaching, and engaging in collegial observation.

In response to the above-mentioned Flemish decree regarding school-wide language policy-making, the CLE redesigned its professional development courses and approach to supporting the implementation of TBLT. CLE coaches now attempt to build up a closer relationship with school teams, in an effort to construct a shared path towards implementing pedagogic change across the curriculum. The CLE's consultancy and training programs are now informed by the following guiding principles (Berben, 2012; Kotter, 2007; Van den Branden, 2009; Van Gorp \& Versteden, 2020):

- Create among staff members of the school team a sense of urgency and a shared vision and ambition, based on the recognition of teachers' concerns, and aiming to address the problems perceived by the teachers themselves. 
- Create a powerful guiding coalition of teachers and school administrators that supports and articulates this vision and ambition across the school team.

- Define concrete and feasible goals and actions that are aligned with the ambition and vision of the school team and, by doing so, construct a shared language to talk about the innovation and creating short-term wins for the teachers.

- Provide support to teachers throughout the implementation process, e.g., by providing hands-on workshops and jointly developing tasks and tools that help them to implement the innovative actions in their classrooms, and by coaching the teachers on the classroom floor.

- Foster collegial observation and team teaching, so that teachers can learn from, and with, each other.

- Evaluate the effects of the actions using (standardized) tests and observations to inform the school team about their students' progress in acquiring the language of schooling. Use those findings to assess the success of the shared ambition, vision, and actions.

- Create opportunities for all stakeholders to interact and continue the joint reflection and deliberation about the innovation.

The essentials of school-based policy

One constant in all the principles mentioned above is that a school team shares a sense of urgency around a common cause. That common cause, which functions as the driver for sustained team effort, is likely to be perceived as more compelling by teachers if it is related to what they consider as key areas in their students' development. Designing a school-wide language policy or implementing taskbased language teaching do not constitute goals in their own right, they only become relevant to teachers and principals when they constitute the best possible means to serve a common, urgent, learner- (and learning-)oriented cause. Ultimately, what distinguishes schools with an effective school improvement policy from others is that they see their key mission and do not allow themselves to be distracted from it (Van den Branden, 2019).

To many teachers, "school-wide language policy" sounds like an umbrella term with which they cannot identify and which they mainly associate with the work of others. That will be even more the case if they cannot link it to operational goals which they believe are of crucial importance to their learners and themselves as professionals. Quite interestingly, the PIRLS-shock has indeed led to an increasing awareness among Flemish school teams regarding the crucial importance of their pupils' reading comprehension skills. Building on this renewed sense of urgency, many primary school teams are now eager again to participate 
in new government-funded, school-based, practice-oriented coaching trajectories aiming to raise the quality of reading education, and raising students' reading comprehension skills.

In response, the CLE has carried out a government-subsidized research review into the features of effective reading education and translated them in five practice-oriented, key principles that are easy to interpret for teachers. In view of the fact that the five principles are strongly in line with the basic principles of taskbased language teaching, chances are that a greater number of teachers will be more motivated to try out task-based principles, particularly if they believe those can help to reach the central goal of helping kids to read better. The implementation of TBLT may be served by acknowledging that teachers do not want to implement TBLT per se; rather, they want to support their pupils' development and do so in relatively comfortable and rewarding conditions.

Determining and sharing focused, learner-oriented goals together can also help teachers to break their professional isolation and engage in collegial collaboration. If a primary school team decides together that they will make a concerted team effort to improve their students' reading comprehension skills because that is considered crucial for their school career and chances in life, team members may be pushed to follow up their students' development over the course of many school years more closely. Moreover, such a clear focus may also motivate teachers to exchange thoughts and ideas on concrete tasks and classroom activities.

At this point, researchers, syllabus developers and school counsellors can make a valuable contribution by (a) informing teachers in clear, practice-oriented terms about the research that is most relevant to those very specific teacher concerns, and (b) providing them with clear, worked-out examples of how those research-based principles can be translated into classroom activities that serve the key mission. In turn, this will help teachers to get their heads round abstract and complex terms, such as "differentiation" and "task".

\section{TBLT revisited}

The concept of "task" constitutes a fine example of a pedagogical concept that many teachers have been found to be struggling with (Carless, 2004; Erlam, 2016; Van den Branden, 2006c). Implementing task-based language teaching in a primary school will become particularly complex if some team members associate "task" with "anything a student is asked to do in a classroom", others with exercises focusing on discrete units, and still others with communicative, goaloriented activities. Some successful Flemish examples of task implementation reported by Van den Branden (2016) indicate that what helps many teachers in understanding what a task is about is linking several, interlocking tasks to an over- 
arching, motivating goal that students need to reach (e.g., students planning a field trip through the city of Ghent) or to a goal-oriented project (e.g., students designing a library of the future).

Van Gorp, Heidrich Uebel, \& Giupponi (forthcoming) report the same experience with instructors of less commonly taught languages in institutions of higher education in the United States. By identifying a project in which students work toward an overarching goal (e.g., planning a cross-cultural wedding; preparing students for study abroad), teachers were able to see more clearly which tasks students needed to perform in order to achieve that goal. At the same time, a project allows for contextualized language work, and retaining a focus on meaning over a longer stretch of planned teaching (Skehan, 2014, p.257). Interestingly, some of the most successful units or themes in the task-based syllabi for primary education developed by the CLE were also project-based (for example, a task-based science project about the Middle Ages - Bogaert, Van Gorp, Bultynck, Lanssens, \& Depauw, 2006).

Perhaps framing tasks as part of projects or goal-oriented, real-life activities helps teachers keep their eyes on the broader picture and not worry too much about the "taskiness" of each individual classroom activity. The idea of motivating students to engage with a set of tasks necessary to accomplish the goals of a project is in line with the TBLT approach as advocated by Long (2015), and is most often found in the domain of Language for Specific Purposes (LSP). Examples are Gonzalez-Lloret and Nielson (2015) reporting about the effectiveness of a TBLT syllabus for the US Border Patrol, and O'Connell (2015) analysing the language tasks related to police traffic stops. But they can apply to regular classrooms in primary education as well, particularly when teachers cross the boundaries between language courses and other courses in the curriculum (e.g., children setting up a reading project about the Middle Ages) or between school and outside life (e.g., children devising and running a safer road to school campaign). In this respect, Nguyen, Newton, \& Crabbe (2018) provide nice examples of teachers in a leading high school in Vietnam going well beyond their textbooks by creating openended, authentic tasks that strongly engaged the students.

Meanwhile, in Flanders, the journey is continuing. The renewed sense of urgency to lift students' reading comprehension skills, the link of evidence-based principles to a task-based reading approach, and the concerted effort of school teams to implement powerful reading practices across the curriculum show clear promise, but the road is still long. The research reported above point to the difficulty of keeping all teachers across all subjects involved in a sustained effort over a longer period of time. The professional development efforts needed to create such a concerted school-wide dynamic are time intensive and, thus, costly. 
A positive evolution is that, contrary to the ' 90 and early 2000s, pre-service teacher training institutes in Flanders are now paying more attention to principles of task-based language learning and teaching, as well as diversity, equity and inclusion in their core curricula. The effects of this turn in pre-service teacher training on the ability of novice teachers to implement TBLT are still unclear and need to be investigated more closely. For now, there is hope that these new impulses may eventually lead to more efficient and effective language teaching for all students.

\section{Concluding remarks}

The innovation of language education is a gradual, laborious, time-consuming process. The hardest part of the work needs to be done by teachers. Merely producing task-based textbooks will not do the trick, nor will providing professional development courses to individual teachers. Setting up a long-term strategic and systematic innovation process within schools that creates a sense of ownership, is team-based and bottom-up, which is accompanied with on-the-job coaching, and is open to re-evaluation and adaptation holds a lot of promise.

Teams must "make language policy" and they must do so together. But that, in the first place, means that they are prepared to critically reflect on their own classroom practice, observe their colleagues' classroom practice, relate it to what research has to say about effective education and to their ongoing assessment of their students' progress, and modify their practice together to make it work better. With respect to TBLT, this means that school teams define and implement what works for their students in their local context: they collaboratively question their mindsets about what students need in order to develop language, explore and adapt their concept of task and classroom activity, and roll out the most effective approach to language education across grades and subjects. School-wide language policy is, ultimately, a matter of pooling resources, expertise, and experiences that are steeped in practice at the local, bottom-up level, while drawing inspiration from the global research and development activity if those prove to be relevant.

\section{References}

Barber, M., Kihn, P., \& Moffit, A. (2011). Deliverology: From idea to implementation. Washington, DC: McKinsey \& Company.

Berben, M. (2012). Hoe een taalbeleid het beleidsvoerend vermogen van je school kan verhogen. Impuls, 43(2), 88-98. 
Berben, M., Callebaut, I., Colpin, M., Francois, S., Geerts, M., Goethals, M., Vander Meeren, K., Vandommele, G., Van Gorp, K., \& Vanoosthuyze, S. (2007). TotemTaal. Themahandleiding en kopieerbladen 4A. Mechelen: Wolters Plantyn.

Berben, M., Van den Branden, K., \& Van Gorp, K. (2007). We'll see what happens: Tasks on paper and tasks in a multilingual classroom. In K. Van den Branden, K. Van Gorp, \& M. Verhelst (Eds.), Tasks in action: Task-based language education from a classroom-based perspective (pp. 32-67). Newcastle upon Tyne: Cambridge Scholars.

Bogaert, N., Van Gorp, K., Bultynck, K., Lanssens, A., \& Depauw, V. (2006). Task-based language teaching in science education and vocational training tasks. In K. Van den Branden (Ed.), Task-based language education: From theory to practice (pp. 106-128). Cambridge: Cambridge University Press.

https://doi.org/10.1017/CBO9780511667282.006

Breen, M. (1989). The evaluation cycle for language learning tasks. In R. Johnson (Ed.), The Second Language Curriculum (pp. 187-206). Cambridge: Cambridge University Press. https://doi.org/10.1017/CBO9781139524520.014

Carless, D. (2004). Issues in teachers' reinterpretation of a task-based innovation in primary schools. TESOL Quarterly, 38 (4), 639-662. https://doi.org/10.2307/3588283

Castles, A., Rastle, K., \& Nation, K. (2018). Ending the Reading Wars: Reading acquisition from novice to expert. Psychological Science in the Public Interest, 19, 5-51. https://doi.org/10.1177/1529100618772271

Colpin, M., \& Van Gorp, K. (2007). Task-based writing in primary education: The development and evaluation of writing skills through writing tasks, learner and teacher support. In K. Van den Branden, K. Van Gorp, \& M. Verhelst (Eds.), Tasks in action: Task-based language education from a classroom-based perspective (pp. 194-234). Newcastle upon Tyne: Cambridge Scholars.

Devlieger, M., Goossens, G., Labath, T., \& Denolf, B. (2003). Procesevaluatie Voorrangsbeleid Brussel. Leuven/Gent: Steunpunt ICO \& Steunpunt Nederlands als tweede taal.

Devlieger, M., \& Goossens, G. (2003). Productevaluatie Voorrangsbeleid Brussel. Leuven: Steunpunt Nederlands als tweede taal.

Devlieger, M., \& Goossens, G. (2006). Evaluatie van vier jaar Voorrangsbeleid Brussel, een intensieve onderwijsvernieuwing in Brusselse Nederlandstalige basisscholen met een meertalige populatie. Leuven: Steunpunt Nederlands als tweede taal.

Devlieger, M., \& Goossens, G. (2007). An assessment tool for the evaluation of teacher practice in powerful task-based language learning environments. In K. Van den Branden, K. Van Gorp, \& M. Verhelst (Eds.), Tasks in action: Task-based language education from a classroom-based perspective (pp. 92-130). Newcastle upon Tyne: Cambridge Scholars.

Ellis, R. (2009). Task-based language teaching: Sorting out the misunderstandings.

International Journal of Applied Linguistics, 19(3), 221-246.

https://doi.org/10.1111/j.1473-4192.2009.00231.X

Ellis, R., Skehan, P., Li, S., Shintani, N., \& Lambert, C. (2020). Task-based language teaching. Theory and practice. Cambridge: Cambridge University Press.

Erlam, R. (2016). 'I'm still not sure what a task is': Teachers designing language tasks. Language Teaching Research, 20(3), 1-21. https://doi.org/10.1177/1362168814566087

Franck, E., \& Nicaise, I. (2019). Ongelijkheden in het Vlaamse onderwijssysteem: verbetering in zicht? Een vergelijking tussen PISA 2003 en 2015, Report No. SONO/2017/1.3/3, Leuven: HIVA / SONO (Steunpunt Onderwijsonderzoek). 
François, S. (2005). Naar een nieuwe taakgerichte taalmethode voor het basisonderwijs: behoeftenonderzoek (Unpublished research report). Leuven: Centre for Language and Education.

González-Lloret, M., \& Nielson, K. (2015). Evaluating TBLT: The case of a task-based Spanish program. Language Teaching Research, 19, 525-549. https://doi.org/10.1177/1362168814541745

Hargreaves, A., \& Fullan, M. (2012). Professional capital: Transforming teaching in every school. New York, NY: Routledge.

Kotter, J.P. (2007). Leading change. Why transformation efforts fail. Cambridge, MA: Harvard Business School Press.

Kyriakides, L., Creemers, B. P.M., Antoniou, P., Demetriou, D., \& Charalambous, C.Y. (2015). The impact of school policy and stakeholders' actions on student learning: A longitudinal study. Learning and Instruction, 36, 113-124. https://doi.org/10.1016/j.learninstruc.2015.01.004

Kubanyiova, M. (2012). Teacher development in action. Understanding language teachers' conceptual change. London: Palgrave MacMillan.

Littlewood, W. (2014). Communication-oriented teaching: Where are we now? Where do we go from here? Language Teaching, 47, 249-362. https://doi.org/10.1017/S0261444812000134

Lokale inburgerings- en integratiemonitor (2019). Retrieved on 27 January, 2020 from https:// www.statistiekvlaanderen.be/nl/monitor-lokale-inburgering-en-integratie

Long, M. (2015). Second language acquisition and task-based language teaching. Chichester: Wiley Blackwell.

Mourshed, M., Chijoke, C., \& Barber, M. (2010). How the world's most improved school systems keep getting better. London: McKinsey \& Company.

Nguyen, B.T., Newton, J., \& Crabbe, D. (2018). Teacher transformation of textbook tasks in Vietnamese EFL high school classes. In V. Samuda, K. Van den Branden, \& M. Bygate (Eds.), TBLT as a researched pedagogy (pp. 51-70). Amsterdam: John Benjamins. https://doi.org/10.1075/tblt.12.03ngu

O'Connell, S. P. (2015). A task-based language teaching approach to the police traffic stop. TESL Canada Journal, 31, 116. https://doi.org/10.18806/tesl.v31io.1189

Prabhu, N. S. (1987). Second Language Pedagogy. Oxford: Oxford University Press.

Schleicher, A. (2018). World Class. How to build a 21st-century school system. Paris: OECD Publishing. https://doi.org/10.1787/9789264300002-en

Skehan, P. (1998). A cognitive approach to language learning. Oxford: Oxford University Press.

Skehan, P. (2014). Limited attentional capacity, second language performance, and task-based pedagogy. In P. Skehan (Ed.), Processing Perspectives on Task Performance (pp. 211-260). Amsterdam: John Benjamins. https://doi.org/10.1075/tblt.5.08ske

Steunpunt toetsontwikkeling en peilingen (2019). Peiling Nederlands. Lezen, luisteren en schrijven in het basisonderwijs 2018. Leuven: Steunpunt toetsontwikkeling en peilingen.

Tielemans, K., Vandenbroeck, M., Bellens, K., Van Damme, J., \& De Fraine, B. (2019). Het Vlaams Lager Onderwijs in PIRLS 2016. Begrijpend lezen in internationaal perspectief in vergelijking met 2006. Leuven: Centrum voor Onderwijseffectiviteit en - evaluatie, KU Leuven.

Vanbuel, M. (2020). Moving language barriers. A mixed-methods study of the implementation of school-based language policies in primary schools (Unpublished doctoral dissertation). KU Leuven.

Van den Branden, K. (Ed.) (2006a). Task-based language education: from theory to practice. Cambridge: Cambridge University Press. https://doi.org/10.1017/CBO9780511667282 
Van den Branden, K. (2006b). Introduction: Task-based language teaching in a nutshell. In K. Van den Branden, Task-based language education: From theory to practice (pp. 1-16). Cambridge: Cambridge University Press. https://doi.org/10.1017/CBO9780511667282.002 Van den Branden, K. (2006c). Training teachers: Task-based as well? In K. Van den Branden (Ed.), Task-based language education: From theory to practice (pp. 217-248). Cambridge: Cambridge University Press. https://doi.org/10.1017/CBO9780511667282.011

Van den Branden, K. (2009). Diffusion and Implementation of Innovations. In M. H. Long, \& C. J. Doughty, The handbook of language teaching (pp. 659-672). Malden, MA: WileyBlackwell. https://doi.org/10.1002/9781444315783.ch35

Van den Branden, K. (2016). The role of teachers in task-based language education. Annual Review of Applied Linguistics, 36, 164-181. https://doi.org/10.1017/S0267190515000070

Van den Branden, K. (2019). Rethinking schools and renewing energy for learning: Research, principles and practice. New York: Routledge. https://doi.org/10.4324/9781351044318

Vandommele, G., Van den Branden, K., \& Van Gorp, K. (2018). Task-based language teaching. How task-based is it really? In V. Samuda, K. Van den Branden, \& M. Bygate (Eds.), TBLT as a researched pedagogy (pp. 165-197). Amsterdam: John Benjamins. https://doi.org/10.1075/tblt.12.07van

Van Droogenbroeck, F., Lemblé, H., Bongaerts, B., Spruyt, B., Siongers, J., \& Kavadias, D. (2019). TALIS 2018 Vlaanderen - Volume I. Brussel: Vrije Universiteit Brussel.

Van Gorp, K. (2018). Task-based language assessment for L1 and L2 speakers in primary education. Designing a useful task-specification framework. In J. McE. Davis, J. Norris, M. Malone, T. McKay, \& Y.A. Son (Eds.), Useful assessment and evaluation in language education (pp. 131-148). Washington, DC: Georgetown University. https://doi.org/10.2307/j.ctvvngrq.11

Van Gorp, K. (in press). Designing a classroom-based TBLA framework for primary schools: Blurring the lines between teaching, learning and assessment. In M.H. Long \& M. J. Ahmadian (Eds.), The Cambridge handbook of task-based language teaching. Cambridge: Cambridge University Press.

Van Gorp, K., Heidrich Uebel, E., \& Giupponi, L. (forthcoming). Collaboration and Curriculum Development: The design of flexible modules in the Less Commonly Taught Languages Partnership. In A. R. Corin, C. Campbell \& B.L. Leaver (Eds.), Open architecture curricular design: Courses and concepts. Washington, DC: Georgetown University Press.

Van Gorp, K., \& Versteden, P. (2020). Advising linguistically diverse schools on developing a school-wide language policy. In R. M. Beerkens, E. Le Pichon-Vorstman, J.D. ten Thije, \& R. G. J.L. Supheert (Eds.), Enhancing intercultural communication in organizations: Insights from project advisors. Abingdon: Routledge. https://doi.org/10.4324/9781003006794-13 


\section{Address for correspondence}

Kris Van den Branden

Faculteit Letteren

KU Leuven

Blijde-Inkomststraat 21

300o, Leuven

Belgium

kris.vandenbranden@kuleuven.be

\section{Biographical notes}

Kris Van den Branden is a Professor of Linguistics and Head of the Language Teacher Education Department at the Faculty of Arts of the University of Leuven (KU Leuven - Belgium). His research interests are task-based language teaching, the professional development of teachers, innovation in language education, and the role of interaction in second language acquisition.

Koen Van Gorp is Head of Foreign Language Assessment at the Center for Language Teaching Advancement and core faculty in the Second Language Studies Ph.D. Program at Michigan State University. He also serves as a Research Fellow at the Centre for Language and Education (KU Leuven). His research interests are task-based language teaching and assessment, language-in-education policy, critical multilingual awareness and multilingualism. 